\title{
Effects of ochratoxin and T-2 toxin combination on performance, biochemical and immune status of commercial broilers
}

\author{
H. C. Indresh and B. Umakantha
}

Department of Poultry Science,

Veterinary College, Karnantaka Veterinary, Animal and Fisheries Science University, Hebbal, Bangalore, India Corresponding author: H. C. Indresh, Present address: Department of Livestock Production and Management, Veterinary College, Hassan, Karnataka. Email: drindreshpsc@gmail.com.

Received: 24-08-2013, Revised: 08-10-2013, Accepted: 09-10-2013, Published online: 22-11-2013

doi: $10.14202 /$ vetworld.2013.945-949

How to cite this article: Indresh HC and Umakantha B (2013) Effects of ochratoxin and T-2 toxin combination on performance, biochemical and immune status of commercial broilers, Veterinary World 6(11): 945-949.

\begin{abstract}
Aim: To study the effects of Ochratoxin A (OA), T-2 toxin (T-2) and their combinations on the performance, biochemical and immune status of broiler chickens.

Materials and Methods: 168 day-old Cobb broiler chicks, obtained from a commercial hatchery were divided by Complete Randomized Design into four groups of three replicates and fourteen chicks per replicate, with dietary treatments of 0.0 (control), 1 ppm OA, 2 ppm T-2 and their combination (1 ppm OA + 2.0 ppm T-2). The chicks were housed in deep litter independent conventional system with feed and water ad libitum throughout the experimental study. Body weight and feed intake were recorded weekly. At the end of the trial, blood was collected and was analyzed for total protein, serum albumin, uric acid and the activities of gamma glutamyl transferase (GGT) and alanine amino transferase (ALT) and antibody titers against ND and IBD using ELISA technique.

Results: The toxin treated birds exhibited a significant $(\mathrm{P}<0.05)$ decrease in the body weights and weight of lymphoid organs. A significant $(\mathrm{P}<0.05)$ reduction in serum total protein, albumin and increase in serum uric acid levels were observed in toxin treated birds. The serum alanine amino transferase (ALT) and gamma glutamyl transferase (GGT) levels were decreased and antibody titers against Newcastle disease (ND) and Infectious Bursal Disease (IBD) were decreased significantly (P $\leq 0.05$ ).
\end{abstract}

Conclusion: The presence of OA and T-2 in the diet showed depressing effects on performance, biochemical and immunological parameters indicating their adverse effects on the general health of broilers.

Key words: biochemical parameters, broilers, immune status, ochratoxin, T-2 toxin,

\section{Introduction}

Feed ingredients and compounded feeds used in poultry production by virtue of their moisture content are highly susceptible to the growth of mould, which produces toxic metabolites during their growth referred to as mycotoxins. The fungal contamination of feedstuffs occurs at various stages of production, harvesting, handling, processing and storage. Cocontamination of feedstuffs with multiple mycotoxins is a common scenario [1].

T-2 is a highly toxic trichothecene mycotoxin produced by different Fusarium species, mainly Fusarium sporotrichoides to a lesser extent by $F$. poae [2]. Similarly Ochratoxin A (OA), a nephrotoxic mycotoxin mainly produced by Aspergillus ochraceus and Penicillium viridicatum, has been shown to contaminate a wide variety of cereals and feed stuffs and is extremely toxic to domestic fowls. Ochratoxin A is classified as the second most important mycotoxin in terms of economic losses worldwide, aflatoxin being the first [3].

The effects of OA and T-2 toxins in poultry were

Copyright: The authors. This article is an open access article licensed under the terms of the Creative Commons Attribution License (http://creativecommons.org/licenses/by/2.0) which permits unrestricted use, distribution and reproduction in any medium, provided the work is properly cited. found to be quite pronounced in young broiler chicks resulting in poor growth rate and poor feed efficiency. In addition, these toxins have been implicated in causing immunosuppression in young birds thereby resulting in economic losses to the poultry farmers. Ochratoxin A and T-2 toxin affects immune function by decreasing the size of vital immune organs, such as thymus, spleen, and lymph nodes, and several immune cells within these tissues thereby causing immunosuppression $[4,5]$.

Hence, an attempt has been made in this study to evaluate the effect of Ochratoxin, T-2 toxin and their combination on performance, biochemical parameters and immune status in commercial broiler chicken.

\section{Materials and Methods}

Ethical approval: The birds were sacrificed as per the standard procedures and after due permission from the Institutional Animal Ethics committee (No. 03 PSCLPM/IAEC/2004-2006 dt 14.07.2005) of Veterinary College, Bangalore.

Experimental animals and design: One hundred and sixty eight, unsexed one-day old commercial Cobb broiler chicks were wing banded, weighed and assigned to a $2 \mathrm{X} 2$ factorial arrangement with control (0.0), OA (1 ppm), T-2 (2.0ppm) and combination of 1 
Table-1. Effect of individual and combined toxicities of ochratoxin and T-2 toxin on body weight ( $\mathrm{g}$ ) of broiler chickens from 0-5 wks of age (Mean+SE)

\begin{tabular}{lllll}
\hline Treatment & $\mathbf{1}^{\text {st }}$ week & $\mathbf{2}^{\text {nd }}$ week & $\mathbf{3}^{\text {rd }}$ week & $\mathbf{4}^{\text {th }}$ week \\
\hline Control & $135.20 \pm 0.34^{\mathrm{a}}$ & $314.0 \pm 2.17^{\mathrm{ab}}$ & $615.6 \pm 2.22^{\mathrm{a}}$ & $1013 \pm 1.94^{\mathrm{a}}$ \\
OA & $80.40 \pm 1.10^{\text {bc }}$ & $111.9 \pm 3.28^{\mathrm{c}}$ & $231.5 \pm 3.54^{\mathrm{c}}$ & $446.4 \pm 3.72^{\mathrm{c}}$ \\
T-2 & $131.0 \pm 1.36^{\mathrm{a}}$ & $304.3 \pm 0.74^{\mathrm{b}}$ & $582.9 \pm 4.24^{\mathrm{b}}$ & $981.3 \pm 5.22^{\mathrm{b}}$ \\
OA +T-2 & $75.37 \pm 1.87^{\mathrm{c}}$ & $98.33 \pm 3.66^{\mathrm{d}}$ & $193.73^{\mathrm{a}}$ & $1282.2 \pm 4.15^{\mathrm{c}}$ \\
\hline
\end{tabular}

Means within each column bearing common superscript do not differ significantly $(P<0.05)$

ppm OA +2.0 ppm T-2 (OA+T-2) in a Completely Randomized Design manner, forming a total of 4 dietary treatments with three replicates and fourteen chicks per replicate in each group. Each replicate group of chicks were housed in an independent pen of conventional deep litter house. Chicks in all the replicates were reared up to five week of age under uniform standard conditions throughout the study. Brooding was done till three weeks of age using incandescent bulbs. Each pen was fitted with an automatic bell type drinker and a hanging tubular feeder. Chicks were provided continuous light throughout the study.

Toxin production: OA and T-2 were produced using the pure culture of Aspergillus ochraceus MTCC 4643 and Fusarium sporotrichoides MTCC 1894 (Source: Microbial Type Culture Collection and Gene Bank, IMT, Chandigarh, 160 036, India) grown on Czapek's agar and oatmeal agar, respectively. Then OA and T-2 toxin was extracted as described by [6,7] and quantified by thin layer chromatography (TLC) as described by [8].

Diet formulation: Basal diet was formulated and compounded to meet the nutrient requirements of commercial broilers during the starter (0-3 wks) (2895 $\mathrm{Kcal} / \mathrm{kg} \mathrm{ME}$ and $20.84 \% \mathrm{CP}$ ) and finisher (4-5 wks) (2994 Kcal/kg ME \& $18.58 \%$ CP) feed. Chicks were provided ad libitum feed and water throughout the study. To this basal diet, required quantities of contaminated culture materials were added to attain dietary levels of $1.0 \mathrm{ppm}$ of ochratoxin and $2.0 \mathrm{ppm}$ of $\mathrm{T}-2$ toxin to each of the toxin containing diets. Compounded experimental diets were analyzed for mycotoxin contents were finally cross-checked by TLC method of analysis. Feeding of test diets commenced at first day of age and continued till the termination of experiment at five weeks of age. Chicks were vaccinated against Newcastle Disease (ND) on 7th day using F1 strain and against Infectious Bursal Disease (IBD) on 14th day using intermediate strain (Ventri's Biologicals, Bangalore, India). Both the vaccines were given by oculonasal and ocular routes.

Data collection: Body weight and feed intake were recorded weekly. At the end of the trial, blood was collected in non-heparinized tubes from six birds in each treatment ( 3 males and 3 females) by puncturing the brachial vein during 5 th week of age. Serum was separated after 8 to 10 hours as per the standard procedures [9] and was stored at $-20^{\circ} \mathrm{C}$ for subsequent analysis. The individual serum samples were analyzed for total protein, serum albumin, uric acid and the activities of gamma glutamyl transferase (GGT) and alanine amino transferase (ALT) were determined using automatic analyzer (Boehringer Mannhein Hitachi 704 automatic analyzer, Japan), antibody titers against ND and IBD using ELISA technique. The birds were sacrificed and liver, kidney, gizzard, spleen, bursa of Fabricius and thymus were extracted and weighed. The weights were adjusted to one $\mathrm{kg}$ live weight and the treatment means were calculated.

Statistical analysis: The experimental data were analyzed statistically by using the General Linear Model procedure of Statistical Analysis System [10]. Duncan multiple range test was employed for comparison of the means [11]. The result of this study was subjected to one way ANOVA test.

\section{Results and Discussion}

The data of effect of different dietary treatments on growth performance, organ weights, immune response and biochemical parameters are presented in Table 1,2 and 3 .

Growth performance: Body weights were significantly $(\mathrm{P}<0.05)$ lower beginning with first week for $\mathrm{OA}$ and OA plus T-2 treatments during third week for T-2 treatment and this reduction in body weights continued throughout the study. The lowest body weight was seen in group fed with combination of OA and T-2 toxin, whereas highest body weight was recorded in control diet. Our findings on reduction in body weights are consistent with earlier reports of feeding OA $[12,13]$, $\mathrm{T}-2[14,15]$ and OA plus T-2 combination [17]. Growth depression effects of OA and T-2 appears to have primarily resulted by their inhibitory action on protein synthesis and nutrient utilization [18].

Organ weights: Compared with those of controls, relative weights of liver, kidney and gizzard were significantly $(\mathrm{P}<0.05)$ increased in the groups receiving Ochratoxin A or T-2 toxin, singly and in combination, whereas relative weight of pancreas was not altered. Ochratoxin A plus T-2 combination fed group showed significant $(\mathrm{P}<0.05)$ increase in relative liver, kidney and gizzard weights followed by $\mathrm{OA}$ (and $\mathrm{T}-2$ fed group, respectively). These findings agree with the results of $[18,19,20]$ for OA, [21, 22] for T-2 and $[18,23]$ for OA plus T-2 combination treatments. The increase in relative weights of liver could be attributed to increased lipid metabolism in liver due to impaired 
Table-2. Effect of individual and combined toxicities of ochratoxin and T-2 toxin on organ weights ( $\mathrm{g} / \mathrm{kg}$ live wt.) of broiler chickens at $5^{\text {th }}$ wk of age $($ Mean \pm SE)

\begin{tabular}{|c|c|c|c|c|c|c|c|}
\hline Treatment & Liver & Kidney & Pancreas & Gizzard & Spleen $^{\text {NS }}$ & Bursa & Thymus \\
\hline
\end{tabular}

Means within each column bearing common superscript do not differ significantly $(P<0.05)$

Table-3. Effect of individual and combined toxicities of ochratoxin and T-2 toxin on Immune and Biochemical parameters of broiler chickens at $5^{\text {th }}$ wk of age $($ Mean \pm SE)

\begin{tabular}{llllll}
\hline Treatment & ND titer & IBD titer & $\begin{array}{l}\text { Serum protein } \\
(\mathbf{g} \%)\end{array}$ & $\begin{array}{c}\text { Serum Albumin } \\
(\mathbf{g} \%)\end{array}$ & $\begin{array}{l}\text { Uric acid } \\
(\boldsymbol{\mu g} / \mathbf{d} \mathbf{)})\end{array}$ \\
\hline Control & $4756.0 \pm 90.22^{\mathrm{a}}$ & $4404.0 \pm 45.82^{\mathrm{a}}$ & $2.93 \pm 0.13^{\mathrm{ab}}$ & $1.25 \pm 0.08^{\mathrm{a}}$ & $675.6 \pm 12.72^{\mathrm{d}}$ \\
OA & $3438.0 \pm 49.2^{\mathrm{c}}$ & $3024.0 \pm 73.04^{\mathrm{d}}$ & $1.88 \pm 0.02^{\mathrm{cd}}$ & $0.76 \pm 0.01^{\mathrm{b}}$ & $1712.0_{ \pm} 11.38^{\mathrm{a}}$ \\
T-2 & $3255.0 \pm 75.92^{\mathrm{b}}$ & $3713.0 \pm 67.51^{\mathrm{c}}$ & $2.60 \pm 0.06^{\mathrm{bc}}$ & $1.17 \pm 0.06^{\mathrm{a}}$ & $1507.0 \pm 5.28^{\mathrm{b}}$ \\
OA +T-2 & $3411.0 \pm 57.45^{\mathrm{c}}$ & $2993.0 \pm 63.25^{\mathrm{d}}$ & $1.84 \pm 0.03^{\mathrm{d}}$ & $0.78 \pm 0.01^{\mathrm{b}}$ & $1664.0 \pm 58.69^{\mathrm{ab}}$ \\
\hline
\end{tabular}

Means within each column bearing common superscript do not differ significantly $(P<0.05)$

fat metabolism which brings appreciable changes in the general functioning and gross appearance of liver. The effects on gizzard are believed to be due to severe inflammation and the resultant thickening of the gastric mucosa [19]. Increase in kidney weight was more likely to be due to enlargement and hypertrophy of proximal convoluted tubules and infiltration of lymphoid cells as suggested by [24].

Lymphoid organs: The relative weight of thymus was significantly $(\mathrm{P}<0.05)$ decreased in the groups receiving OA or T-2 toxin singly and in combination, whereas relative weights of bursa and spleen were not altered compared to that of control (Table-2). The relative weight of bursa and thymus were significantly $(\mathrm{P}<0.05)$ depressed in the OA plus $\mathrm{T}-2$ combination fed group, followed by $\mathrm{OA}$ and T-2 alone fed groups as compared to control group at fifth week of age. Mycotoxins are known to cause immunosuppression in chickens and concomitantly reduce the relative sizes of bursa of Fabricius and thymus responsible for immunological competence [25]. The reduction in size of lymphoid organs (bursa and thymus) might have been due to necrosis and cellular depletion by the mycotoxins. The findings of the study were comparable to the reports of $[19,26]$.

Immune response: The titer values against $\mathrm{ND}$ and antibody titres for IBD were significantly $(\mathrm{P}<0.05)$ decreased by $\mathrm{OA}, \mathrm{T}-2$ toxin alone and OA plus $\mathrm{T}-2$ toxin combination treatments (Table-2). The highest depression was recorded in the group fed combined OA plus T-2 toxin followed by OA and T-2 toxin alone fed groups. This depression in titer values are clear indication of immunodepressing effects of mycotoxins on humoral antibody response. The reduction of antibody titers could be due to mycotoxins inhibiting DNA and protein synthesis through impairment of amino acid transport and m-RNA transcription, resulting in lowered level of antibody production [27, $28,29]$. The reduced antibody titers in T-2 toxicosis is in agreement with the reports of [30] who reported significant reduction of antibody titers against ND and IBD values in commercial broilers fed 3 ppm T-2 toxin.

Serum biochemistry: A significant $(\mathrm{P}<0.05)$ reduction in serum total protein, albumin and increase in serum uric acid levels were observed in OA alone and OA plus $\mathrm{T}-2$ toxin combination fed groups. In T-2 toxin alone treated group, serum uric acid values significantly $(\mathrm{P}<0.05)$ reduced from control values at fifth week of age (Table-3). The highest depression of serum total protein, albumin and highest increased levels of serum uric acid was recorded in the group fed OA plus T-2 toxin combination, followed by OA and T-2 toxin alone fed groups. The mechanism by which these toxins cause decrease in serum protein levels is thought to be due to the impairment of protein synthesis by inhibiting m-RNA transportation by binding to DNA. The findings of the present study were in agreement with $[18,22,31]$.

Serum enzyme activity: Serum GGT activity was significantly $(\mathrm{P}<0.05)$ increased by $\mathrm{OA}$ and $\mathrm{OA}$ plus $\mathrm{T}$ 2 toxin combination as compared to control group, but the level of GGT was not altered by T-2 toxin alone treatment (Table-3). Highest level of serum GGT activity was recorded in OA plus $\mathrm{T}-2$ combination group followed by $\mathrm{OA}$ and $\mathrm{T}-2$ alone fed groups and lowest level of activity was observed in group fed control diet. The activity of serum ALT was significantly $(\mathrm{P}<0.05)$ decreased in chicks fed $\mathrm{OA}$ alone and OA plus T-2 toxin combination as compared to control group at fifth week of age. The lowest level of serum ALT activity was seen in OA plus T-2 combination group followed by OA and T-2 fed alone groups and the highest level of serum ALT activity was recorded in control diet. The increased serum GGT levels noted could be due to the sequalae of hepatocyte degeneration and subsequent leakage of enzymes into the circulation. The results of altered levels of serum GGT and serum ALT by feeding OA were in agreement with reports of [32-35]. 


\section{Conclusion}

The OA and T-2 toxins have been known to occur concomitantly in grain samples and the toxicological consequences of this interaction appear to be significant. The interaction between OA and T-2 for many parameters measured was significant and clearly indicates synergistic effect. Although understanding the mechanism of this interaction is beyond the scope of this study, this mycotoxin combination should be of major concern to the poultry industry due to its synergistic toxicity as they coexist in feeds and feed ingredients.

\section{Authors' contributions}

HCI carried out the experiment and drafted the final manuscript. BU designed the experiment, guided during the experiment and helped in analysis of the data. Both authors read and approved the final manuscript.

\section{Acknowledgements}

The authors are thankful to The Dean, Veterinary College, Karnataka Veterinary, Animal and Fisheries Sciences University (KVAFSU), Bangalore, India for providing the basic facilities for the conduct of the research. Research funds of Department of Poultry Science, Veterinary College, KVAFSU, Bangalore was utilized for this study

\section{Competing interests}

The authors declare that they have no competing interests.

\section{References}

1. Anjum, M. A.,. Sahota, A. W., Akram, M. and Ali, I. (2011) Prevalence of mycotoxins in poultry feed ingredients in Punjab. The J. Anim. Pl. Sci. (21)2:117-120.

2. Pozzo, L., Salamano, G., Mellia, E., Gennero, M.S., Doglione, L., Cavallarin, L., Tarantola, M., Forneris. G. and Schiavone, A. (2013) Feeding a diet contaminated with ochratoxin A for chickens at the maximum level recommended by the EU for poultry feeds $(0.1 \mathrm{mg} / \mathrm{kg}) .1$. Effects on growth and slaughter performance, haematological and serum traits. Journal of Animal Physiology and Animal Nutrition. 97 (1): 13-22.

3. Manning, R.O. and Wyatt, R.D. (1984) Toxicity of Aspergillus ochraceus contaminated wheat and different chemical forms of ochratoxin A in broiler chicks. Poult. Sci. 63:458-465.

4. Xue, C. Y., Wang, G. H., Chen, F., Zhang, X. B., Bi, Y. Z. and Cao, Y. C. (2010) Immuno pathological effects of ochratoxin A and T-2 toxin combination on broilers. Poultry Science. 89(6): 1162-1166.

5. Iheshiulor, O.O.M., Esonu, B.O., Chuwuka, O.K., Omede, A.A., Okoli, I.C. and Ogbuewu, I.P. (2011) Effects of mycotoxins in animal nutrition: A review. Asian J. Anim. Sci. 5: 19-33.

6. Rukmini, C. and Bhat, R.V. (1978) Occurrence of T-2 toxin in Fusarium infested sorghum from India. Journal of Agricultural and Food Chemistry. 26: 647-649.

7. Romer, T.R. (1975) Screening method for the detection of aflatoxins in mixed feeds and other agricultural commodities with subsequent confirmation and quantitative measurement of aflatoxins in positive samples. Journal of AOAC international. 58: 500-506.

8. AOAC. (1995) Official Methods of Analysis. 16th Ed.,
Association of Official Analytical Chemists, Washington, D.C.

9. Calnek, B.W., Barnes, H.J., Beard, C.W., Reid, W.M. and Yoder Jr. H.W. (1992) Diseases of Poultry, 9th Edn., Wolfe Publishing, Ltd., USA.

10. SAS. (2000). Statistical Analysis Systems User's Guide: Statistics. SAS Institute Inc., Cary, NC, USA.

11. Duncan, D.B. (1955) Multiple range and multiple F tests. Biometrics. 11: 1-42.

12. Sakthivelan, S.M. and Sudhakar Rao. S.V. (2010) Effect of Ochratoxin A on Body Weight, Feed Intake and Feed Conversion in Broiler Chicken. Veterinary Medicine International. 1: 1-4.

13. Prakash, K., Umakantha, B., Devegowda, G., Gowdh, C.V. and Krishnappa. G. (2000) Effect of individual and combined supplementation of vitamin $E$ and selenium on the performance of broiler chicks fed Ochratoxin-A. Indian J. Ani. sci. 70:2: 197-199.

14. Nesic, K., Resanovic, R., Jakic-Dimic, D. and Nesic, V. (2011) Efficiency of various feed additives on the performance of broilers treated with $\mathrm{T}-2$ toxin. Biotechnology in Animal Husbandry 27 (3): 705-711.

15. Arvind, K.L., Patil, V.S., Devegowda, G., Umakantha, B. and Ganpule, S.P. (2003) Efficacy of Esterified glucomannan to counteract Mycotoxicosis in naturally contaminated feed on performance, serum biochemical and hematological parameters in broilers. Poult. Sci., 82: 571-576.

16. Eriksen, G.S and Pettersson. H. (2004) Toxicological evaluation of trichothecenes in animal feed. Animal Feed Science and Technology. 114(1/4): 205-239.

17. Manafi, M., Umakantha, B., Noor Ali, M. and Narayana Swamy, H.D. (2012) Study of the Combination Effects of Aflatoxin and T-2 Toxin on Performance Parameters and Internal Organs of Commercial Broilers. Global Veterinaria 8 (4): 393-396.

18. Hassan, Z., Khan, M. Z., Khan, A. and Javed, I. (2010) Pathological responses of white Leghorn breeder hens kept on Ochratoxin A contaminated feed. Pakistan Veterinary Journal. 30: 118-123.

19. Azarakhsh, Y., Sabokbar, A. and Bayat, M. (2011) Incidence of the Most Common Toxigenic Aspergillus Species in Broiler Feeds. Global Veterinaria. 6: 73-77.

20. Agawane, S.B. and Lonkar, P.S. (2004) Effect of probiotic containing saccharomyces boulardii on experimental ochratoxicosis in broilers; haematobiochemical studies. Journal of Vet. Science. 5(4): 359-367.

21. Verma, J., Johri, T.S., Swain, B.K. and Ameena. S. (2004) Effect of graded levels of flatoxin, Ochratoxin and their combinations on the performance and immune response of broilers. British Poultry Science. 45(4): 512-518.

22. Awaad, M.H.H., Abdel Alim, G.A., Madian, K., Kawkab, Ahmed, A. and EI-nabarawy, A. (2005) Prevention of chicken Ochratoxicosis immune dysfunction by probiotics. Veterinary Medical Journal Giza. 53(2): 473-488.

23. Curtui, V.G. (2000) Effects of feeding a Fusariumpoae extract and a natural zeolite to broiler chickens. Mycotoxin Research. 16(1): 43-52:39.

24. Nataraj, T.H., Swamy, H.D.N., Vijayasarathi, S.K., Kumar, B.S. and Prakash, G.C. (2004) Pathomorphological study of liver and kidneys in aflatoxicosis and T-2 toxicosis in broiler chickens. Indian Journal of Ani. Science. 74(9): 944-945.

25. Kubena, L.F., Huff, W.E., Harvey, R.B., Corrier, D.E., Phillips, T.D. and Rottinghans, G.E. (1989) Individual and combined toxicity of deoxynivalenol and T-2 toxin in broiler chicks. Poultry. Sci. 68: 622-626.

26. Dwivedi, P. and Burns, R.B. (1984) Pathology of ochratoxicosis A in young broiler chicks. Res. Vet. Sci. 36: 92-103.

27. Jayaramu G.M., Satyanarayana M.L., Ravikumar, P. and Narayanaswamy H.D. (2012). Evaluation of the Immune Status of Broiler Chicken during Ochratoxin, Citrinin and Their Combined Toxicity. Int. J. Adv. Bio. Res. 2(4): 756-759. 
28. Kalorey, D.R., Kurkure, N.V., Ramgoankar, J.S., Sakhare, P.S., Shubhangi Warke and Nagot, N.K. (2005) Effect of polyherbal feed supplement "Growell" during induced aflatoxicosis, ochratoxicosis and combined mycotoxicosis in broilers. Asian Australian Journal of Animal Sciences. 18(3): 375-383.

29. Kamalavenkatesh, P., Vairamuthu, S., Balachandran, C., Manohar, B.M. and Raj, G.D. (2005) Immunopathological effect of the mycotoxins cyclopiazonic acid and T-2 toxin on broiler chickens. Mycopatholgia. 159(2): 273-279.

30. Wang G.H., Xue C.Y., Chen F., Ma Y.L., Zhang A.B., Bi Y.Z. and Cao Y.C. (2009) Effects of combinations of ochratoxin A and $\mathrm{T}-2$ toxin on immune function of yellow-feathered broiler chickens. Poultry Science. 88: 504-510.

31. Zahoor-ul-Hassan, Khan, M.Z., Khan, A. and Javed, I. (2010) Pathological responses of White Leghorn breeder hens kept on ochratoxin A contaminated feed. Pakistan Veterinary Journal 30(2): 118-123.
32. Raju, M.V.L.N. and Devegowda, G. (2000) Influence of esterified glucomannan on performance and organic morphology, serum biochemistry and haematology in broilers exposed to individual and combined mycotoxicosis (aflatoxin, ochratoxin and T-2 toxin). Br. Poult. Sci. 41: 640650.

33. Mujahid, H., Hashmi, A.S., Anjum, A.A., Waris, A and Tipu, Y. (2012) Detoxification potential of Ochratoxin by yeast sludge and evaluation in broiler chicks. The Journal of Animal and Plant Sciences. 22(3): 601-604.

34. Yang, D.J., Chang, W. K., Byoung, K.A., Jong S.A. and Radka, B. (2013) Effects of ochratoxin A and preventive action of A mycotoxin-deactivation product in broiler chickens. Veterinarija IR Zootechnika. 61: 22-29.

35. Jelena, N.T., Trailovi, S., Mirjana, D. and Ili, V. (2013) Blood serum protein status in broilers fed with increasing concentrations of Ochratoxin A. Acta Veterinaria (Beograd). 63( 1): 77-88.

$* * * * * * * *$ 